\title{
Comparison Between Niemann's and Finite Element Method for the Estimation of Maximum Allowable Stress of Meshing Spur Gear Teeth at Highest Point of Single Tooth Contact
}

\author{
Konstandinos G. Raptis, Theodore N. Costopoulos and Andonios D. Tsolakis \\ Department of Mechanical Engineering, Laboratory of Machine Elements, \\ National Techical University of Athens, 9 Iroon Polytexneiou Av, GR-15780 Zografou, Athens, Greece
}

Received 2012-06-07, Revised 2012-08-27; Accepted 2012-08-27

\begin{abstract}
Purpose of this study is the consideration of loading and contact problems encountered at rotating machine elements and especially at toothed gears. The later are some of the most commonly used mechanical components for rotary motion and power transmission. This fact proves the necessity for improved reliability and enhanced service life, which require precise and clear knowledge of the stress field at gear tooth. This study investigates the maximum allowable stresses occurring during spur gear tooth meshing computed using Niemann's formulas at Highest Point of Single Tooth Contact (HPSTC). Gear material, module, power rating and number of teeth are considered as variable parameters. Furthermore, the maximum allowable stresses for maximum power transmission conditions are considered keeping the other parameters constant. After the application of Niemann's formulas to both loading cases, the derived results are compared to the respective estimations of Finite Element Method (FEM) using ANSYS software. Comparison of the results derived from Niemann's formulas and FEM show that deviations between the two methods are kept at low level for both loading cases independently of the applied power (either random or maximum) and the respective tangential load.
\end{abstract}

Keywords: Highest Point of Single Tooth Contact (HPSTC), Finite Element Method (FEM)

\section{INTRODUCTION}

First systematic attempt to calculate the position of critically stressed point is attributed to Lewis (1882), who considered that the inscribed isosceles parabola tangent to the dedendum of the tooth flank defines the critically stressed point which is located at the point of tangency at the side which is loaded by tensile stresses.

The "30 degrees tangent" is another method which argues that the critically stressed point is independent of the load location. Instead, it is located at a specific point at the tooth root. Although this method is adopted the ISO standards, (Kawalec et al., 2006), it is approximate and applicable only to low stressed gears.

Methods, such as AGMA standard and DIN (Kawalec et al., 2006), Heywood's semi-empirical method (Heywood, 1962) and Dolan-Broghamer's (Dolan and Broghamer,1942) empirical formula, can be found at references and are recommended for the determination of the precise stress level caused by the phenomenon of stress concentration at gear tooth root

According to method proposed by DIN 39901987 and ISO 6336 1996, standards the bending stresses calculation at gear tooth root is based on the concept of "30 degrees tangent" (Heywood, 1962), which proves to be a disadvantage. Thus, this method is quite approximate and should not be applied to the design of high loaded gearings.

Heywood's method (Heywood, 1962), is applied for the determination of maximum real stress at critically stressed point at the root of a stubby beam with constant width. This method was later modified in order to make more precise prediction of the critical point which is located at a lower position from then on.

\section{MATERIALS AND METHODS}

The previously mentioned methods of maximum stress calculation at gear tooth root will not be applied at 
the present study, because the determination of the necessary geometric features, especially at the critical region of gear tooth fillet which requires more precise computations, is a time-consuming procedure. Instead, the applied method assumes that the maximum load during gear tooth meshing is applied to the Highest Point of Single Tooth Contact (HPSTC), (Spitas et al., 2005).

\subsection{Gear-Tooth Strength at the Critically Stressed Point of Root}

According to gearing theory, the total load PN applied to the gear tooth along contact path of the transverse tooth section can be seen at Fig. 1 and the tangential component of gear tooth load at pitch point $\mathrm{C}$ can be found using the following relation Eq. 1:

$\mathrm{P}_{\mathrm{u}}=\mathrm{P}_{\mathrm{n}} \cdot \cos \beta_{\mathrm{o}}=\mathrm{P}_{\mathrm{N}} \cdot \cos \alpha_{\mathrm{on}} \cdot \cos \beta_{\mathrm{o}}$

Assuming that gear tooth is a stubby cantilever beam fixed at dedendum circle, it can be easily seen that gear tooth loading is maximum when $\mathrm{P}_{\mathrm{N}}$ is applied at the addendum circle, as seen at Fig. 1.

When applied at the addendum circle, normal load $\mathrm{P}_{\mathrm{N}}$ does not attain its maximum value. If we shift $\mathrm{P}_{\mathrm{N}}$ to point $\mathrm{M}$, which is located on the axis of symmetry of the gear tooth, it can be resolved giving a tangential component Eq. 2:

$\mathrm{P}_{\mathrm{u}}=\mathrm{P}_{\mathrm{N}} \cdot \cos \alpha^{\prime}$

and a radial component Eq. 3:

$\mathrm{P}_{\mathrm{R}}=\mathrm{P}_{\mathrm{N}} \cdot \sin \alpha^{\prime}$

At the critically stressed point, PU causes the following bending moment Eq. 4:

$\mathrm{M}_{\mathrm{B}}=\mathrm{P}_{\mathrm{N}} \cdot \mathrm{e}_{\mathrm{f}} \cdot \cos \alpha^{\prime}$

Resulting in a bending stress of Eq. 5:

$\sigma_{\mathrm{b}}= \pm \frac{\mathrm{M}_{\mathrm{B}}}{\mathrm{W}_{\mathrm{B}}}= \pm \frac{\mathrm{P}_{\mathrm{N}} \cdot \mathrm{e}_{\mathrm{f}} \cdot \cos \alpha^{\prime}}{\mathrm{b}_{\mathrm{o \delta}} \cdot \mathrm{s}_{\mathrm{f}}^{2} / 6}$

and a shear stress $\tau_{\Delta}$ (positioned at the critical point bo $\delta$ ef ) Eq. 6:

$\tau_{\Delta}=\frac{\mathrm{P}_{\mathrm{N}} \cdot \cos \alpha^{\prime}}{\mathrm{b}_{\mathrm{o} \delta} \cdot \mathrm{S}_{\mathrm{f}}}$

while $P_{R}$ causes a compressive stress Eq. 7:

$\sigma_{d}=-\frac{P_{N} \cdot \sin \alpha^{\prime}}{b_{o \delta} \cdot s_{f}}$

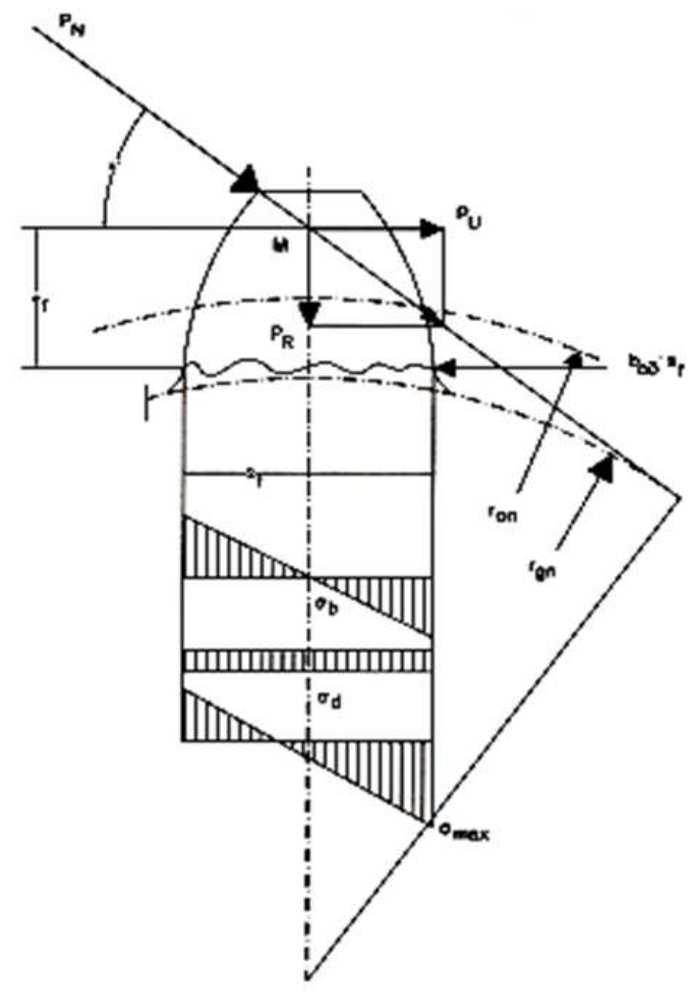

Fig. 1. Gear tooth loading

Shear stress, compared to the bending and compressive stresses which are collinear and normal to the shear stress, is small enough and can be neglected. The maximum normal stress is the compressive one with a value of Eq. 8:

$\sigma_{\max }=\sigma_{\mathrm{b}}+\sigma_{\mathrm{d}}$

Or Eq. 9:

$\sigma_{\max }=\frac{6 \cdot \mathrm{P}_{\mathrm{N}} \cdot \mathrm{e}_{\mathrm{f}} \cdot \cos \mathrm{a}^{\prime}}{\mathrm{b}_{\mathrm{o} \delta} \cdot \mathrm{s}_{\mathrm{f}}^{2}}+\frac{\mathrm{P}_{\mathrm{N}} \cdot \sin \mathrm{a}^{\prime}}{\mathrm{b}_{\mathrm{o} \delta} \cdot \mathrm{s}_{\mathrm{f}}}$

As gear thickness $b$ is related to gear tooth length $b_{o \delta}$ with the following relation Eq. 10:

$\mathrm{b}=\mathrm{b}_{\mathrm{o} \delta} \cdot \cos \beta_{\mathrm{o}}$

And according to the previous discussion, we can obtain the following result Eq. 11:

$\sigma_{\max }=\frac{P_{u} \cdot q_{k}}{b \cdot m}$

Where Eq. 12: 
$q_{k}=\frac{m_{n} \cdot\left(6 \cdot e_{f} \cdot \cos \alpha^{\prime} / s_{f}+\sin \alpha^{\prime}\right)}{s_{f} \cdot \cos \alpha_{o n}}$

Coefficient $\mathrm{q}_{\mathrm{k}}$ depends on the number of pinion teeth and rack cutter shift during pinion generation.

In order to take into account the meshing of more than one tooth pairs when the load is applied at the addendum circle, we introduce the overlap coefficient or contact ratio for the transverse tooth section at Eq. 11. Thus Eq. 13:

$\sigma_{\max }=\frac{\mathrm{P}_{\mathrm{u}} \cdot \mathrm{q}_{\mathrm{k}}}{\mathrm{b} \cdot \varepsilon \cdot \mathrm{m}} \leq \sigma_{\varepsilon \pi}$

where, $\sigma_{\varepsilon \pi}$ is the allowable stress for the critical point, which depends on gear material, tangential velocity at pitch point and gear meshing mode. In more detail.

For a tangential velocity at pitch point lower than or equal to $5 \mathrm{~m} \mathrm{sec}^{-1}$, we have Eq. 14:

$\sigma_{\varepsilon \pi}=\frac{\sigma_{\mathrm{B}}}{2 \cdots 3}$

For a tangential velocity at pitch point greater than 5 $\mathrm{m} / \mathrm{sec}$ and a single trend of rotation, we have Eq. 15:

$\sigma_{\varepsilon \pi}=\frac{\sigma_{b w}}{1,5 \ldots .2}$

Where:

$\sigma_{\mathrm{B}} \quad=$ The tensile strength of gear material

$\sigma_{\mathrm{bw}}=$ The bending strength of gear material

\subsection{Highest Point of Single Tooth Contact (HPSTC) During Tooth Meshing}

It is proven that the normal load $\mathrm{P}_{\mathrm{N}}$ on a gear tooth is not maximum when applied at the addendum circle. As shown in Fig. 2 during gear tooth meshing, from point A where tooth contact begins to point $\mathrm{A}^{\prime}$ of tooth contact path and from point $\mathrm{B}^{\prime}$ to point $\mathrm{B}$, where tooth contact completes, two pairs of teeth are in contact simultaneously. On the other hand, between points $\mathrm{A}^{\prime}$ and $\mathrm{B}^{\prime}$ only a single tooth pair is in contact subjected to the total load.

It can, thus, be assumed that the worst loading condition for a tooth of gear 1 does not occur when the load is applied to the highest addendum point (point B), because the total load is distributed at two pairs of gear teeth at this point, but at point $\mathrm{B}^{\prime}$ of contact path where only a single pair of gear teeth is meshing (Niemann, 1982; Spitas et al., 2005).

Point $\mathrm{A}^{\prime}$ is defined The Lowest Point of Single Tooth Contact (LPSTC) and point $\mathrm{B}^{\prime}$ is the Highest Point of Single Tooth Contact (HPSTC) for gear 1.

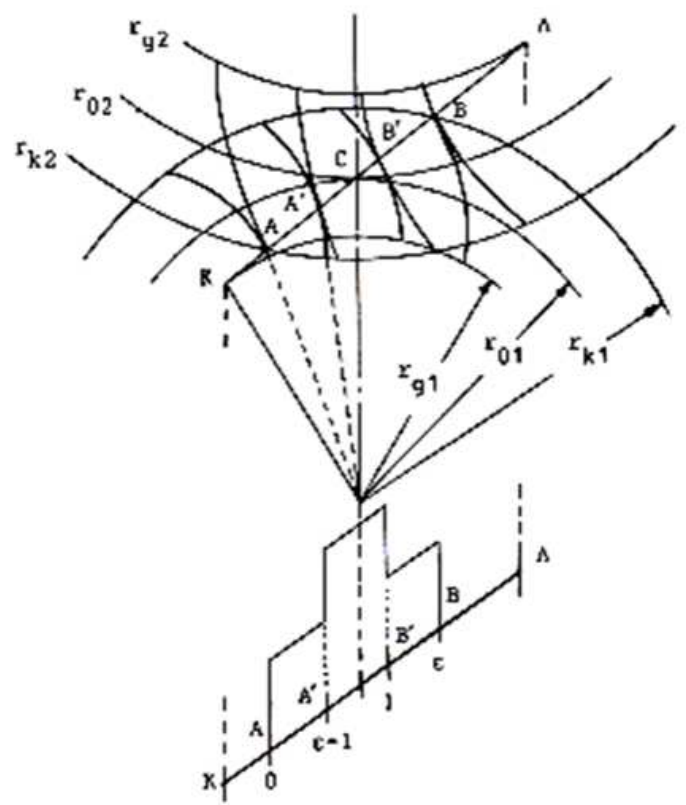

Fig. 2. (a) Meshing teeth profiles of a gear transmission stage (b) Positions of tooth load variation

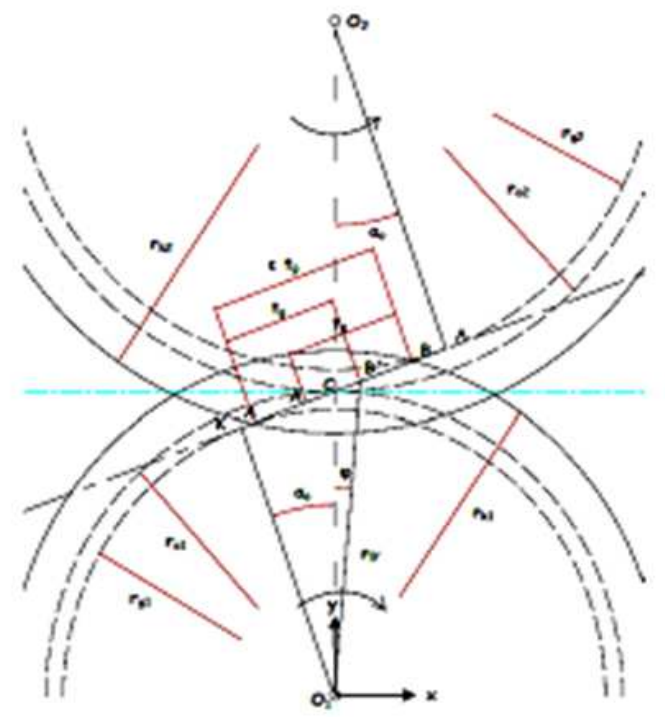

Fig. 3. Geometric determination of HPSTC

That is, during portion $\mathrm{A}^{\prime} \mathrm{B}^{\prime}$ of the contact path only a single tooth of each gear is loaded, whereas during portions $\mathrm{AA}^{\prime}$ and $\mathrm{BB}^{\prime}$ the load is distributed to two teeth of each gear. Thus, we can infer that the maximum gear tooth loading occurs at a point on part $\mathrm{A}^{\prime} \mathrm{B}^{\prime}$ of the contact path (Spitas et al., 2005). 
Determination of the point of maximum stresses during gear meshing (Fig. 3) is as follows:

$$
\begin{aligned}
& \mathrm{AB}=\varepsilon \cdot \mathrm{t}_{\mathrm{g}}=\mathrm{AC}+\mathrm{CB} \\
& \mathrm{AC}=\sqrt{\left(\mathrm{r}_{\mathrm{o} 2}+\mathrm{m}\right)^{2}-\mathrm{r}_{02}^{2} \cdot \cos ^{2} \alpha_{\mathrm{o}}}-\mathrm{r}_{02} \cdot \sin \alpha_{0} \\
& \mathrm{BC}=\sqrt{\left(\mathrm{r}_{01}+\mathrm{m}\right)^{2}-\mathrm{r}_{01}^{2} \cdot \cos ^{2} \alpha_{0}}-\mathrm{r}_{01} \cdot \sin \alpha_{0}
\end{aligned}
$$

Substituting Eq. (17) and (18) to Eq. (16) results Eq. 19:

$$
\begin{aligned}
& A B=\sqrt{\left(r_{02}+m\right)^{2}-r_{02}^{2} \cdot \cos ^{2} \alpha_{o}} \\
& +\sqrt{\left(r_{01}+m\right)^{2}-r_{01}^{2} \cdot \cos ^{2} \alpha_{0}}-\left(r_{01}+r_{02}\right) \cdot \sin \alpha_{0}
\end{aligned}
$$

HPSTC is located at point $\mathrm{B}^{\prime}$. During parts $\mathrm{AA}^{\prime}$ and $\mathrm{B}^{\prime} \mathrm{B}$ of the contact path, load is transmitted through two pairs of gear teeth, while during part $\mathrm{A}^{\prime} \mathrm{B}^{\prime}$ only a single pair of gear teeth is subjected to the total load. The lengths of parts $\mathrm{AB}^{\prime}$ and $\mathrm{A}^{\prime} \mathrm{B}$ equal the gear circular pitch, tg, at the base circle. Thus, position of HSPTC is determined according to Fig. 3 as follows Eq. 20 and 21:

$$
\begin{aligned}
& \mathrm{AC}=\sqrt{\left(r_{02}+m\right)^{2}-r_{02}^{2} \cdot \cos ^{2} \alpha_{0}}-r_{02} \cdot \sin \alpha_{0} \\
& C^{\prime}=A^{\prime}-A C=t_{g}-A C=\pi \cdot m \cdot \cos \alpha_{0}-A C
\end{aligned}
$$

Using triangle $\mathrm{O}^{\prime} \mathrm{B}^{\prime} \mathrm{C}$, radius $\mathrm{rB}^{\prime}$ can be calculated according to the following Eq. 22:

$$
\mathrm{r}_{\mathrm{B}^{\prime}}=\sqrt{\mathrm{r}_{01}^{2}+\mathrm{CB}^{\prime 2}-2 \cdot \mathrm{r}_{01} \cdot \mathrm{CB}^{\prime} \cdot \cos \left(\alpha_{0}+90^{\circ}\right)}
$$

Cartesian coordinates of point $\mathrm{H}$ are: $(\mathrm{x}, \mathrm{y})=\left(\mathrm{r}_{\mathrm{B}^{\prime}}\right.$ $\left.\sin \varphi, \mathrm{r}_{\mathrm{B}^{\prime}} \cos \varphi\right)$.

\subsection{Application of Niemann's Formulas}

Next we will investigate the deviation between results of the referenced maximum stress formulas and computerized results of the finite element method. For this purpose, tangential load $\mathrm{P}_{\mathrm{u}}$ is applied to the highest point of single tooth contact during gear tooth meshing.

Ten different gear materials with increasing quality are assumed, starting from GS 52 and resulting to $42 \mathrm{Cr}$ V6. Number of pinion teeth is constant $\mathrm{z}_{1}=18$, while ten sets of parameter are considered:

$$
\begin{array}{ll}
\text { Number of gear teeth: } \mathrm{z}_{2}= & 20,50,80 \text { and } 100 \\
\text { Module: } \mathrm{m} & =1,2,3,4,5 \text { and } 6 \mathrm{~mm} \\
\text { Tooth length: } \mathrm{b}_{1} & =10,20,30,40 \text { and } 50 \mathrm{~mm} \\
\text { Input power: } \mathrm{P}_{\mathrm{W}} & 10,18,27,34,42,53,58, \\
& 63,65 \text { and } 70 \mathrm{~kW}
\end{array}
$$

The previous sets of parameter values are identical for each type of gear material.

Next, maximum stress for each set is calculated. Table 1-3 show the detailed results for three types of gear materials, while Table 4 gathers the results derived for all gear materials.

For the determination of tangential load Pu applied to the highest point of single tooth contact during gear tooth meshing, the above parameters $\left(\mathrm{m}, \mathrm{b}_{1}, \mathrm{z}_{1}, \mathrm{z}_{2}, \mathrm{P}_{\mathrm{w}}\right)$ are set to MITCalc software for each gear material and the value of load are computed automatically. This value is identical for each gear material assuming a common parameter set.

Using Eq. (13), (14) and (15), we determine the allowable and the maximum stress, depending on the ultimate tensile strength of each material. It was found that the maximum stress is constant for a common set of parameters and independent of the value of

\begin{tabular}{|c|c|c|c|c|c|c|c|c|}
\hline $\begin{array}{l}\text { Gear } \\
\text { material }\end{array}$ & $\begin{array}{l}\text { Module } \\
(\mathrm{mm})\end{array}$ & $\mathrm{Z}_{2}$ & $\begin{array}{l}\text { PW } \\
(\mathrm{kW})\end{array}$ & $\begin{array}{l}\mathrm{P}_{\mathrm{U}} \\
(\mathrm{Nt})\end{array}$ & $\begin{array}{l}\sigma_{\varepsilon \pi} \\
\left(\mathrm{Nt} / \mathrm{mm}^{2}\right)\end{array}$ & $\begin{array}{l}\sigma_{\max } \\
\left(\mathrm{Nt} / \mathrm{mm}^{2}\right)\end{array}$ & $\begin{array}{l}\text { ANSYS } \\
\left(\mathrm{Nt} / \mathrm{mm}^{2}\right)\end{array}$ & $\%$ \\
\hline \multirow[t]{10}{*}{$\overline{\text { GS } 52}$} & 1 & 30 & 10 & $10.611,11$ & 200 & $1.885,79$ & $1.854,00$ & 1.72 \\
\hline & 2 & 50 & 18 & $9.500,00$ & 200 & 432,81 & 425,454 & 1.73 \\
\hline & 2 & 80 & 27 & $14.325,00$ & 200 & 412,70 & 408,265 & 1.09 \\
\hline & 3 & 100 & 34 & $12.025,93$ & 200 & 199,69 & 202,509 & -1.39 \\
\hline & 3 & 100 & 42 & $14.855,56$ & 200 & 173,05 & 175,304 & -1.28 \\
\hline & 4 & 80 & 53 & $14.059,72$ & 200 & 149,31 & 147,224 & 1.41 \\
\hline & 5 & 30 & 58 & $12.308,89$ & 200 & 211,89 & 209,550 & 1.12 \\
\hline & 5 & 50 & 63 & $13.370,00$ & 200 & 440,41 & 433,936 & 1.49 \\
\hline & 6 & 80 & 65 & $11.495,37$ & 173,33 & 157,28 & 159,777 & -1.56 \\
\hline & 6 & 100 & 70 & $12.379,63$ & 173,33 & 83,37 & 82,198 & 1.43 \\
\hline
\end{tabular}
maximum allowable stress, which generally is different for each material.

The maximum allowable stress increases with material quality. Thus, the values of maximum stresses reach the values of the maximum allowable stress.

Using, then, MITCalc software, we import pinion geometry of each material to Solid Works software. Next, the solid model is imported to ANSYS FEM software and the maximum stress at gear tooth root is computed using the finite element method.

Table 1. Deviation between Niemann's method results and FEM (ANSYS) results assuming GS-52 gear material and random transmitted power 
Konstandinos G. Raptis et al. / American Journal of Engineering and Applied Sciences 5 (2) (2012) 205-216

Table 2. Deviation between Niemann's method results and FEM (ANSYS) results assuming Gk-60 gear material and random transmitted power

\begin{tabular}{|c|c|c|c|c|c|c|c|c|}
\hline $\begin{array}{l}\text { Gear } \\
\text { material }\end{array}$ & $\begin{array}{l}\text { Module } \\
(\mathrm{mm})\end{array}$ & $\mathrm{Z}_{2}$ & $\begin{array}{l}\mathrm{PW} \\
(\mathrm{KW})\end{array}$ & $\begin{array}{l}\mathrm{P}_{\mathrm{U}} \\
(\mathrm{Nt})\end{array}$ & $\begin{array}{l}\sigma_{\varepsilon \pi} \\
\left(\mathrm{Nt} / \mathrm{mm}^{2}\right)\end{array}$ & $\begin{array}{l}\sigma_{\max } \\
\left(\mathrm{Nt} / \mathrm{mm}^{2}\right)\end{array}$ & $\begin{array}{l}\text { ANSYS } \\
\left(\mathrm{Nt} / \mathrm{mm}^{2}\right)\end{array}$ & $\%$ \\
\hline \multirow[t]{10}{*}{ Ck 60} & 1 & 30 & 10 & $10.611,11$ & 296,00 & $1.885,79$ & $1.854,00$ & 1.72 \\
\hline & 2 & 50 & 18 & $9.500,00$ & 296,00 & 432.81 & 425,454 & 1.73 \\
\hline & 2 & 80 & 27 & $14.325,00$ & 296,00 & 412,70 & 408,265 & 1.09 \\
\hline & 3 & 100 & 34 & $12.025,93$ & 296,00 & 199,69 & 202,509 & -1.39 \\
\hline & 3 & 100 & 42 & $14.855,56$ & 296,00 & 173,05 & 175,304 & -1.28 \\
\hline & 4 & 80 & 53 & $14.059,72$ & 296,00 & 149,31 & 147,224 & 1.41 \\
\hline & 5 & 30 & 58 & $12.308,89$ & 296,00 & 211,89 & 209,550 & 1.12 \\
\hline & 5 & 50 & 63 & $13.370,00$ & 296,00 & 440,41 & 433,936 & 1.49 \\
\hline & 6 & 80 & 65 & $11.495,37$ & 293,33 & 157,28 & 159,777 & -1.56 \\
\hline & 6 & 100 & 70 & $12.379,63$ & 293,33 & 83,37 & 82,198 & 1.43 \\
\hline
\end{tabular}

Table 3. Deviation between Niemann's method results and FEM (ANSYS) results assuming 35CrMo4 gear material and random transmitted power

\begin{tabular}{|c|c|c|c|c|c|c|c|c|}
\hline $\begin{array}{l}\text { Gear } \\
\text { material }\end{array}$ & $\begin{array}{l}\text { Module } \\
\mathrm{A}(\mathrm{mm})\end{array}$ & $Z_{2}$ & $\begin{array}{l}\mathrm{PW} \\
(\mathrm{kW})\end{array}$ & $\begin{array}{l}\mathrm{P}_{\mathrm{U}} \\
(\mathrm{Nt})\end{array}$ & $\begin{array}{l}\sigma_{\varepsilon \pi} \\
\left(\mathrm{Nt} / \mathrm{mm}^{2}\right)\end{array}$ & $\begin{array}{l}\sigma_{\max } \\
\left(\mathrm{Nt} / \mathrm{mm}^{2}\right)\end{array}$ & $\begin{array}{l}\text { ANSYS } \\
\left(\mathrm{Nt} / \mathrm{mm}^{2}\right)\end{array}$ & $\%$ \\
\hline \multirow{10}{*}{$35 \mathrm{CrMo} 4$} & 1 & 30 & 10 & $10.611,11$ & 352,00 & $1.885,79$ & $1.854,00$ & 1.72 \\
\hline & 2 & 50 & 18 & $9.500,00$ & 352,00 & 432,81 & 425,454 & 1.73 \\
\hline & 2 & 80 & 27 & $14.325,00$ & 352,00 & 412,70 & 408,265 & 1.09 \\
\hline & 3 & 100 & 34 & $12.025,93$ & 352,00 & 199,69 & 202,509 & -1.39 \\
\hline & 3 & 100 & 42 & $14.855,56$ & 352,00 & 173,05 & 175,304 & -1.28 \\
\hline & 4 & 80 & 53 & $14.059,72$ & 352,00 & 149,31 & 147,224 & 1.41 \\
\hline & 5 & 30 & 58 & $12.308,89$ & 352,00 & 211,89 & 209,550 & 1.12 \\
\hline & 5 & 50 & 63 & $13.370,00$ & 352,00 & 440,41 & 433,936 & 1.49 \\
\hline & 6 & 80 & 65 & $11.495,37$ & 456,66 & 157,28 & 159,777 & -1.56 \\
\hline & 6 & 100 & 70 & $12.379,63$ & 456,66 & 83,37 & 82,198 & 1.43 \\
\hline
\end{tabular}

Table 4. Review of deviation between Niemann's and FEM results for ten different gear materials and random power rating

\begin{tabular}{|c|c|c|c|c|c|c|c|c|}
\hline $\begin{array}{l}\text { Gear } \\
\text { material }\end{array}$ & $\begin{array}{l}\text { Module } \\
(\mathrm{mm})\end{array}$ & $\mathrm{Z}_{2}$ & $\begin{array}{l}\mathrm{PW} \\
(\mathrm{kW})\end{array}$ & $\begin{array}{l}\mathrm{P}_{\mathrm{U}} \\
(\mathrm{Nt})\end{array}$ & $\begin{array}{l}\sigma_{\varepsilon \pi} \\
\left(\mathrm{Nt} / \mathrm{mm}^{2}\right)\end{array}$ & $\begin{array}{l}\sigma_{\max } \\
\left(\mathrm{Nt} / \mathrm{mm}^{2}\right)\end{array}$ & $\begin{array}{l}\text { ANSYS } \\
\left(\mathrm{Nt} / \mathrm{mm}^{2}\right)\end{array}$ & $\%$ \\
\hline GS 52 & 1 & 30 & 10 & $10.611,11$ & 200 & $1.885,79$ & $1.854,00$ & 1.72 \\
\hline St 70 & 2 & 50 & 18 & $9.500,00$ & 274.4 & 432,81 & 425,454 & 1.73 \\
\hline $36 \mathrm{Mn} 5$ & 2 & 80 & 27 & $14.325,00$ & 280,00 & 412,70 & 408,265 & 1.09 \\
\hline Ck 60 & 3 & 100 & 34 & $12.025,93$ & 296,00 & 199,69 & 202,509 & -1.39 \\
\hline $37 \mathrm{Cr} 4$ & 3 & 100 & 42 & $14.855,56$ & 314,00 & 173,05 & 175,304 & -1.28 \\
\hline 42 Mnv7 & 4 & 80 & 53 & $14.059,72$ & 320,00 & 149,31 & 147,224 & 1.41 \\
\hline $35 \mathrm{CrMo} 4$ & 5 & 30 & 58 & $12.308,89$ & 352,00 & 211,89 & 209,550 & 1.12 \\
\hline $31 \mathrm{NiCr} 14$ & 5 & 50 & 63 & $13.370,00$ & 372,00 & 440,41 & 433,936 & 1.49 \\
\hline 34CrNiMo6 & 6 & 80 & 65 & $11.495,37$ & 500,00 & 157,28 & 159,777 & -1.56 \\
\hline $42 \mathrm{CrV} 6$ & 6 & 100 & 70 & $12.379,63$ & 566,66 & 83,37 & 82,198 & 1.43 \\
\hline
\end{tabular}

Examples of the derived results using FEM are shown in Fig. 4-7, regarding GG 52, Ck 60, 36Mn 5 and $35 \mathrm{GrMo} 4$ gear materials respectively.

Comparison of the results between the applied methods (Niemann's formulas and FEM) shows a deviation from- $1.56 \%$ to $+1.73 \%$. This $\%$ deviations are common for each material assuming a constant of parameter values, as can be seen at Table 1-4 in detail.

Figure 8 shows a diagram of maximum stress versus gear tooth length resulting from the concentrated results of Table 4.

Then, using trial and error method and MITCal software we find for each material the maximum allowable power Pmax, such that the maximum stress equals allowable stress. Figure 9-12 are some examples of finite element analyses assuming GG 52, St 70, Ck 60 and $5 \mathrm{CrMo} 4$ gear materials, respectively.

Application of the former procedure shows that deviation between the results of maximum stress using Niemann's formulas (Niemann, 1982) and FEM (using ANSYS) lie in the range from $1.56 \%$ to $+1.73 \%$. This percentages are identical for each material with a common set of parameters as can be seen at Table 5-8.

Using the results of Table 8, we can create a diagram of maximum allowable stress versus maximum rated power, as shown in Fig. 13. 
Konstandinos G. Raptis et al. / American Journal of Engineering and Applied Sciences 5 (2) (2012) 205-216

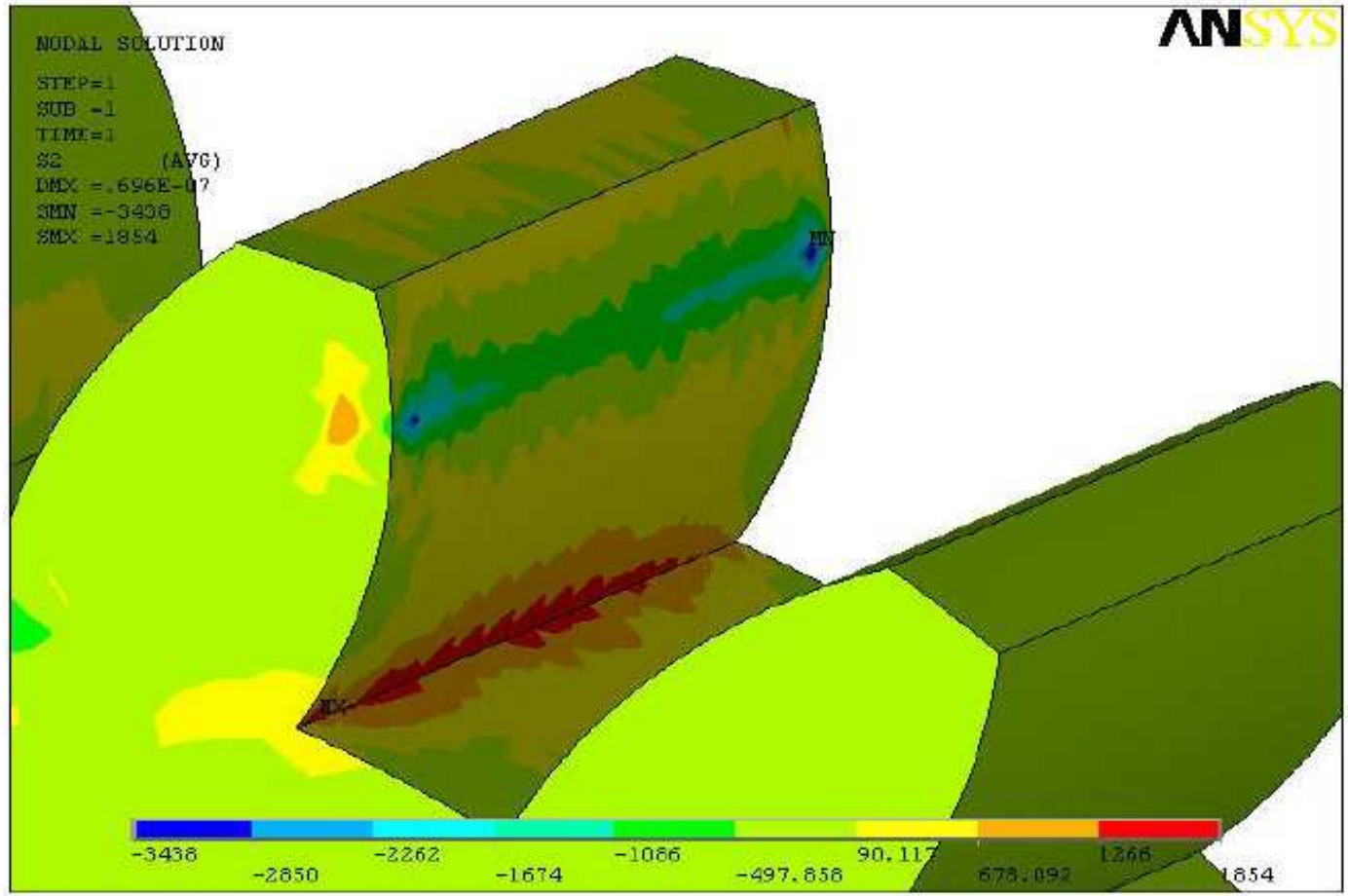

Fig. 4. Gear material: GG52, $\mathrm{m}=1, \mathrm{~b}_{1}=10, \mathrm{z}_{2}=30, \mathrm{PW}=10 \mathrm{KW}, \sigma_{\max }=1885,79 \mathrm{~N} / \mathrm{mm}^{2}$

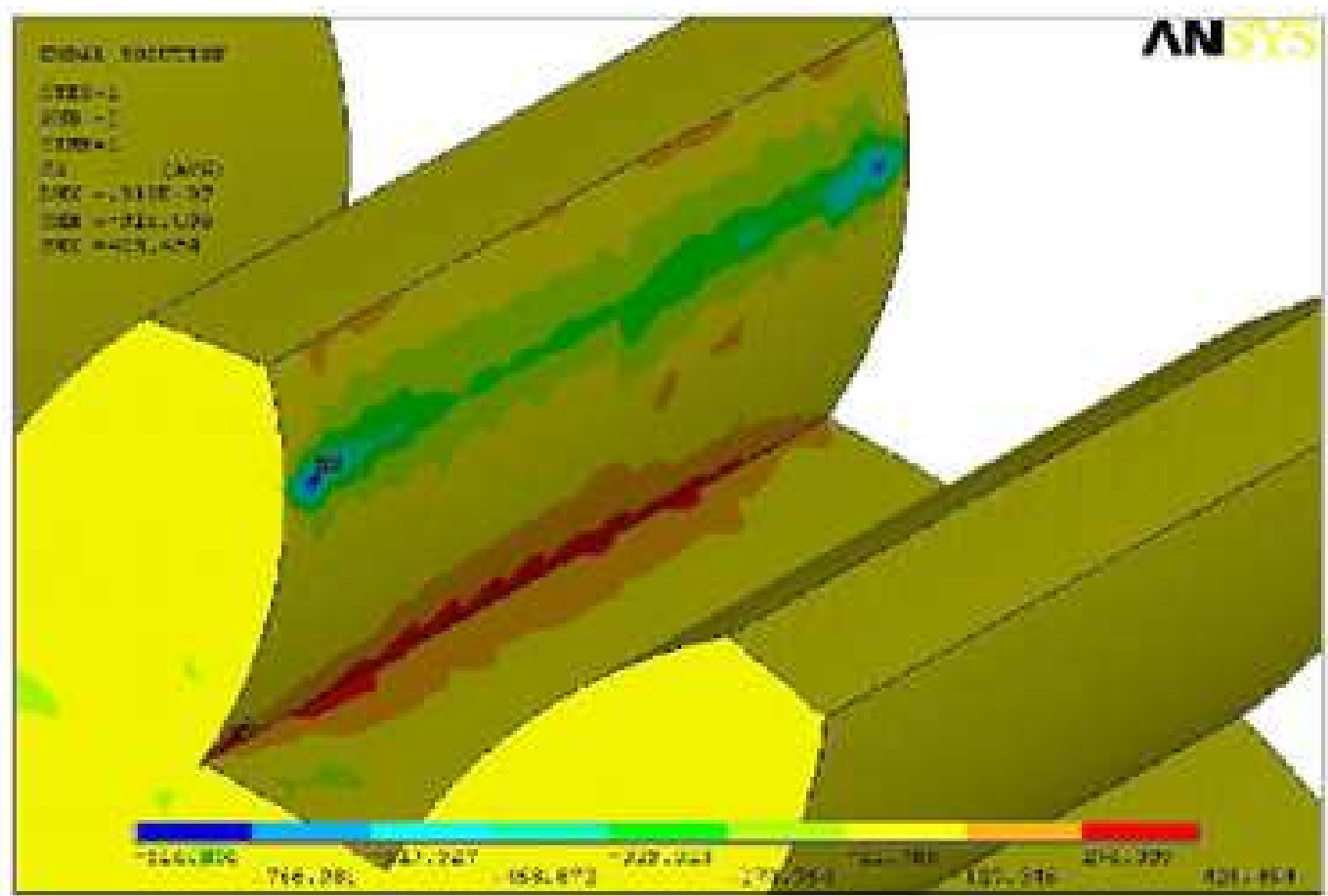

Fig. 5. Gear material: $\mathrm{Ck} 60, \mathrm{~m}=2, \mathrm{~b}_{1}=20, \mathrm{z}_{2}=50, \mathrm{P}_{\mathrm{w}}=18 \mathrm{KW}, \sigma_{\max }=432,81 \mathrm{~N} / \mathrm{mm}^{2}$ 
Konstandinos G. Raptis et al. / American Journal of Engineering and Applied Sciences 5 (2) (2012) 205-216

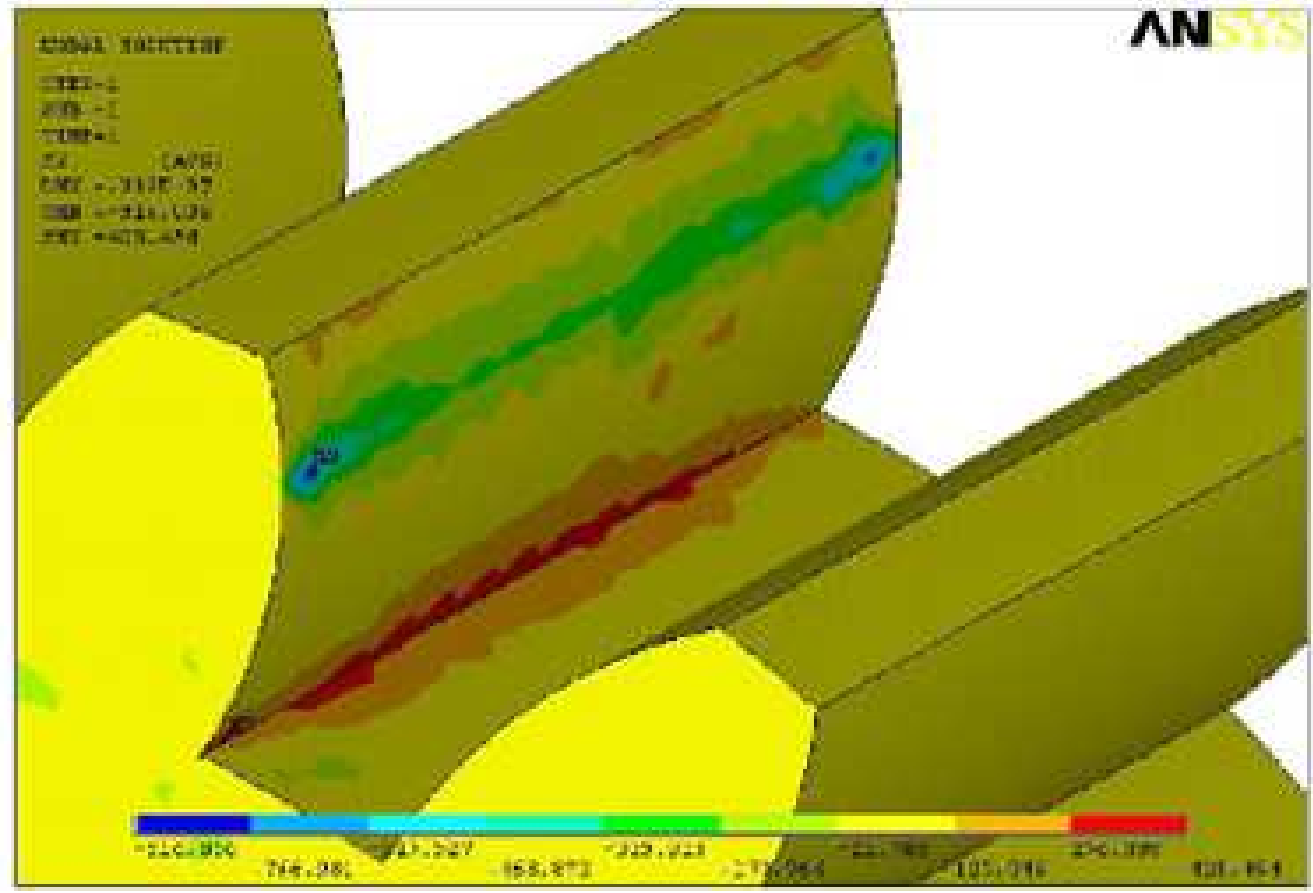

Fig. 6. Gear material: $36 \mathrm{Mn} 5, \mathrm{~m}=2 \mathrm{~mm}, \mathrm{~b}_{1}=30 \mathrm{~mm}, \mathrm{z}_{2}=80 \kappa \alpha \mathrm{l} \mathrm{P}_{\mathrm{w}}=27 \mathrm{KW}$

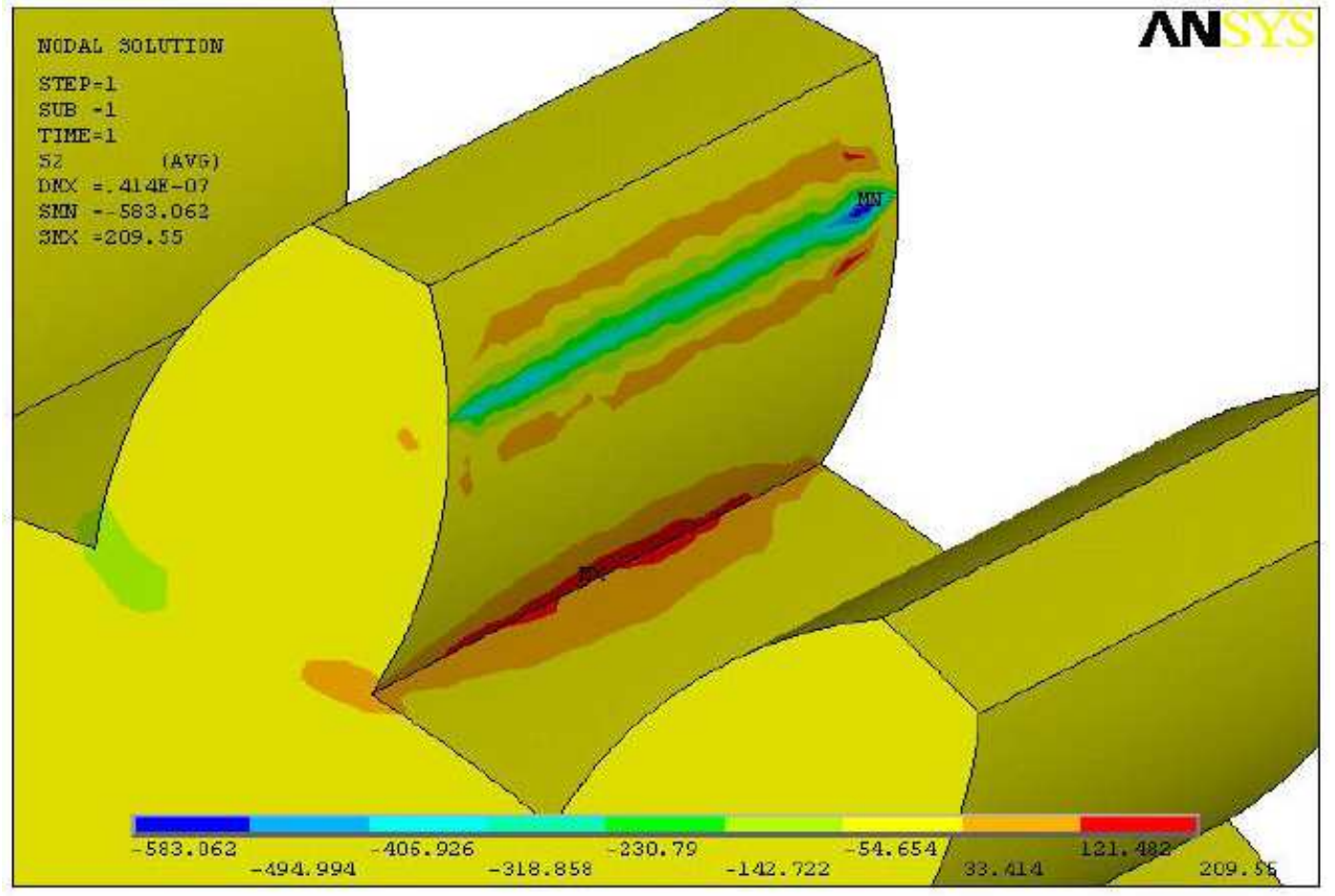

Fig. 7. Gear material: $35 \mathrm{CrMo} 4, \mathrm{~m}=5 \mathrm{~mm}, \mathrm{~b} 1=20 \mathrm{~mm}, \mathrm{z} 2=30 \kappa \alpha \mathrm{Pw}=58 \mathrm{KW}$ 
Konstandinos G. Raptis et al. / American Journal of Engineering and Applied Sciences 5 (2) (2012) 205-216

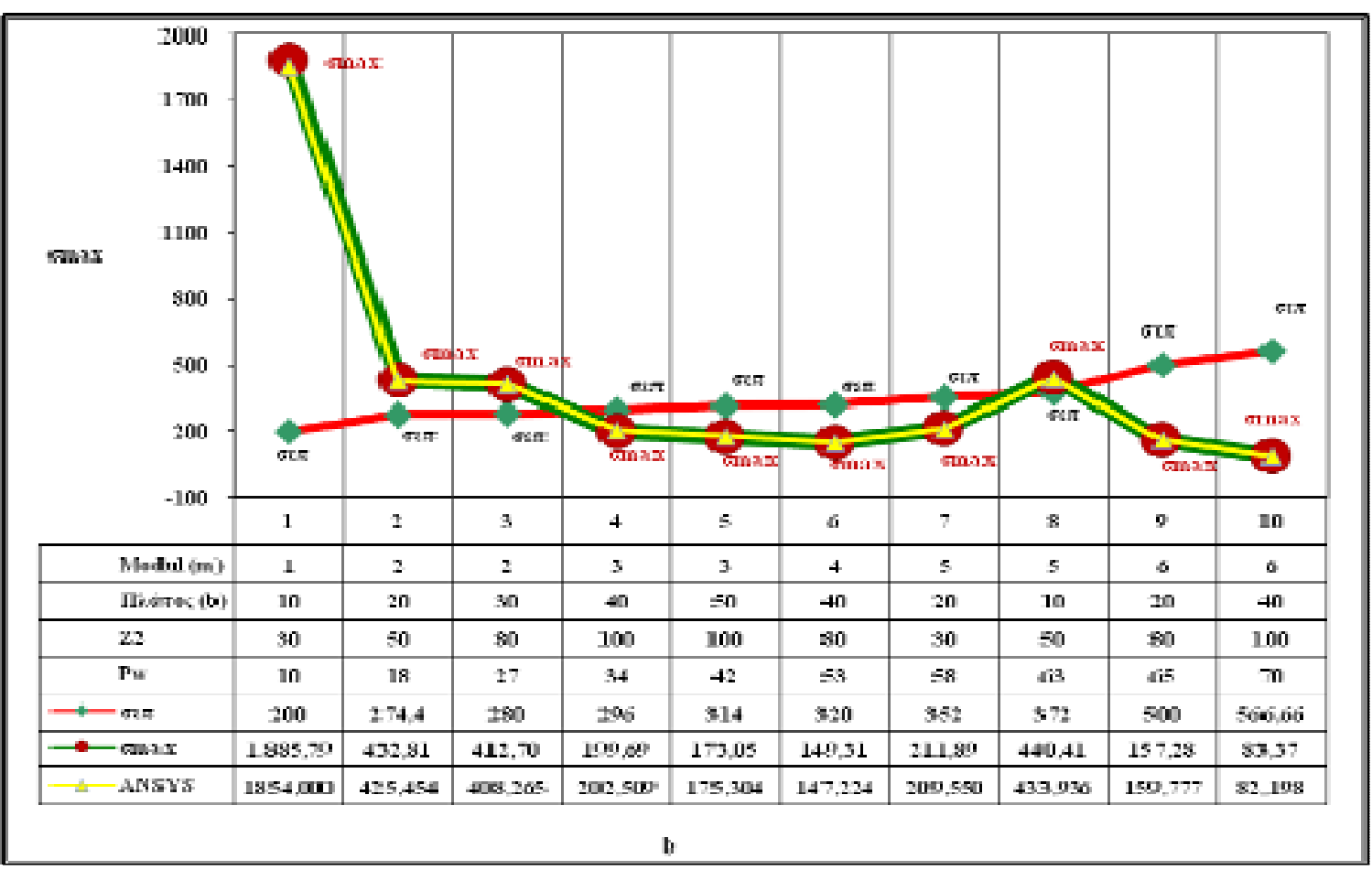

Fig. 8. Diagram of maximum stress $\left(\sigma_{\max }\right)$ versus gear tooth length $(b)$

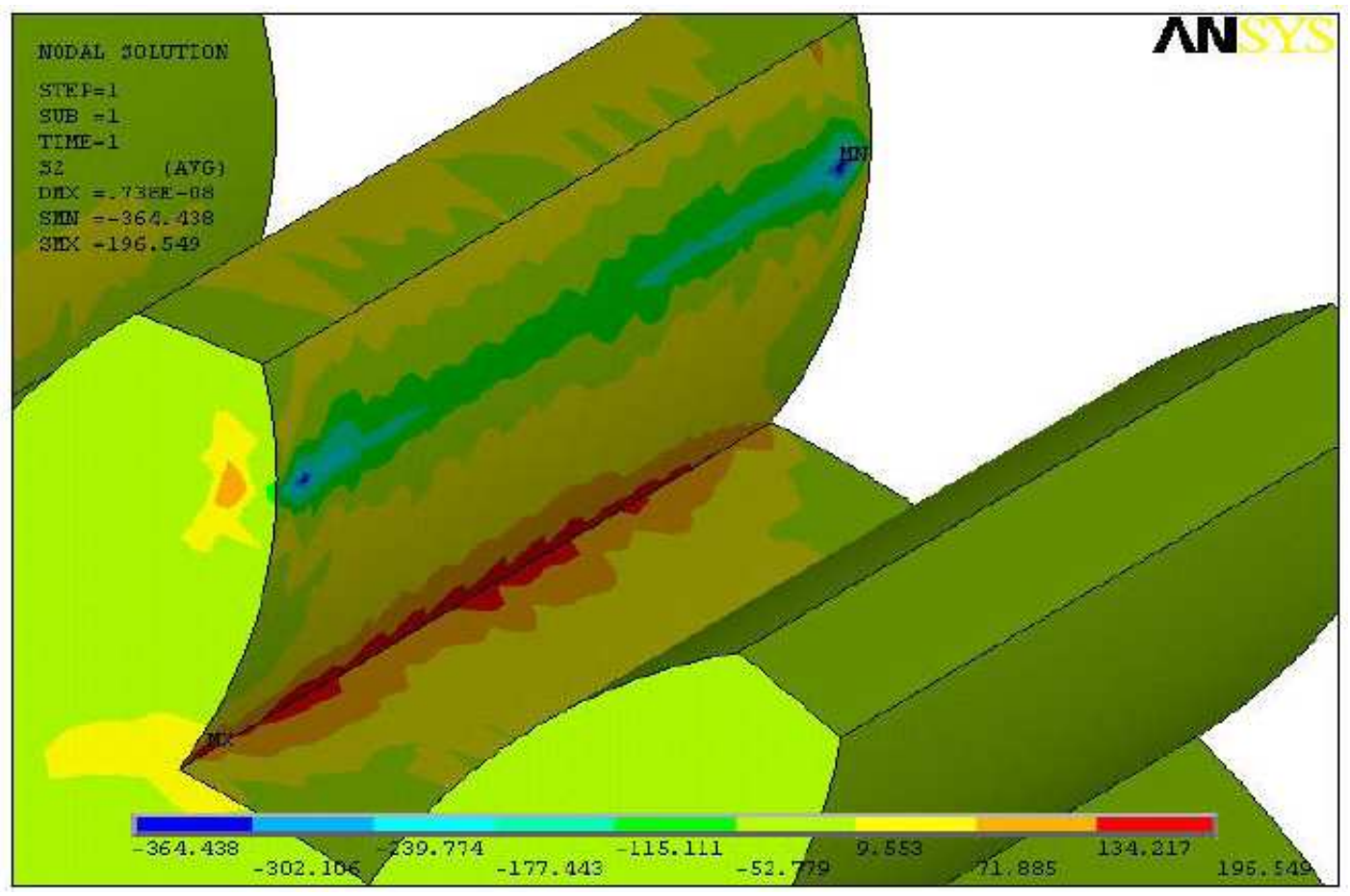

Fig. 9. Gear material: GS 52, $\mathrm{m}=1, \mathrm{~b}_{1}=10, \mathrm{z}_{2}=30, \mathrm{P}_{\mathrm{wmax}}=0.983 \mathrm{~kW}, \sigma_{\max }=199,92 \mathrm{~N} / \mathrm{mm}^{2}$ 
Konstandinos G. Raptis et al. / American Journal of Engineering and Applied Sciences 5 (2) (2012) 205-216

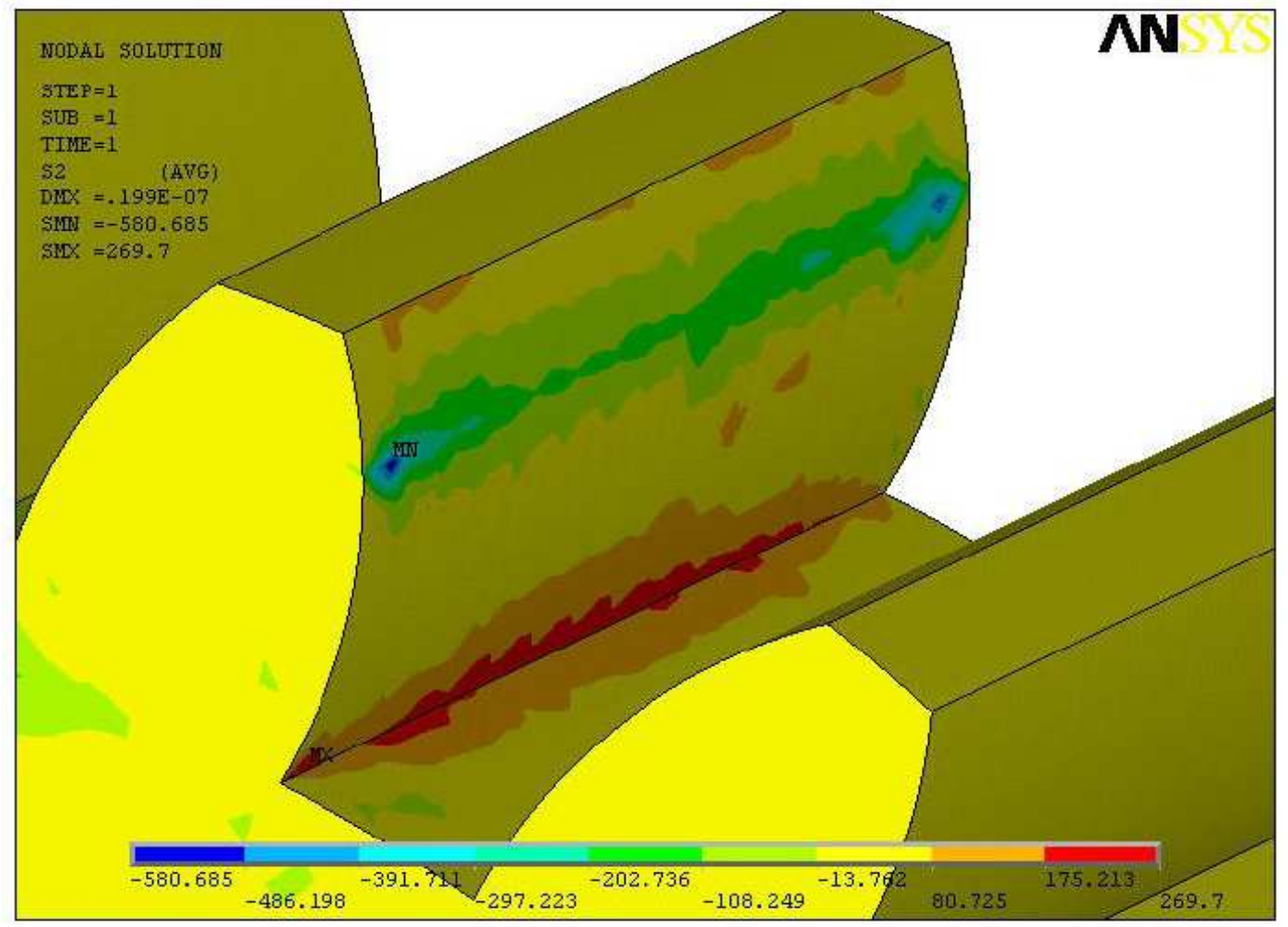

Fig. 10. Gear material: $S t 70, m=2, b_{1}=20, z_{2}=50, P_{w \max }=11.138 \mathrm{~kW}, \sigma_{\max }=274,38 \mathrm{~N} / \mathrm{mm}^{2}$

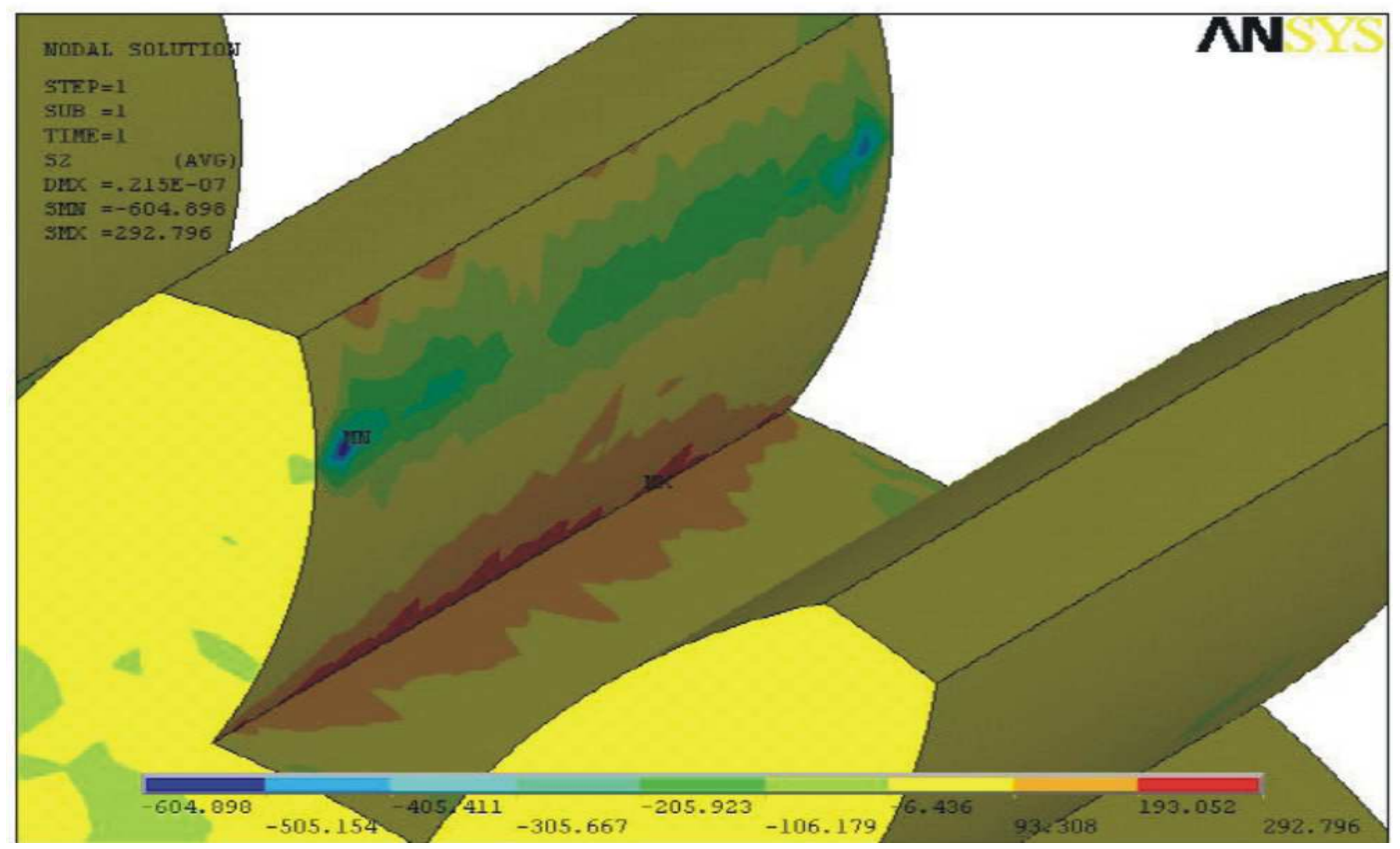

Fig. 11. Gear material: $\mathrm{Ck} 60, \mathrm{~m}=2 \mathrm{~mm}, \mathrm{~b}_{1}=30 \mathrm{~mm}, \mathrm{z}_{2}=80$ and $\mathrm{P}_{\mathrm{wmax}}=18.414 \mathrm{~kW}$ 


\section{RESULTS}

Consideration of the diagram shown in Fig. 8 as well as Table 1-4 derives the following conclusions:

- Maximum stress $\left(\sigma_{\max }\right)$ decreases as module $(\mathrm{m})$ increases

- Maximum stress $\left(\sigma_{\max }\right)$ decreases as gear thickness (b) increases and vice versa

- Tangential load $\left(\mathrm{P}_{\mathrm{u}}\right)$ decreases as module (m) increases, whereas as module (m) decreases tangential load $\left(\mathrm{P}_{\mathrm{u}}\right)$ increases
Consideration of the diagram shown in Fig. 13 as well as Table 5-8 derives the following conclusions:

- Increase of both pinion thickness (b) and module (m) causes an increase of maximum rated power $\left(\mathrm{P}_{\mathrm{wmax}}\right)$

- Maximum rated power $\left(\mathrm{P}_{\mathrm{wmax}}\right)$ decreases as pinion thickness (b) decreases, regardless of the module (m) increase

- Maximum rated power $\left(\mathrm{P}_{\mathrm{wmax}}\right)$ is different for each material and increases with enhanced material quality due to an increase in the maximum allowable stress $\left(\sigma_{\varepsilon \pi}\right)$

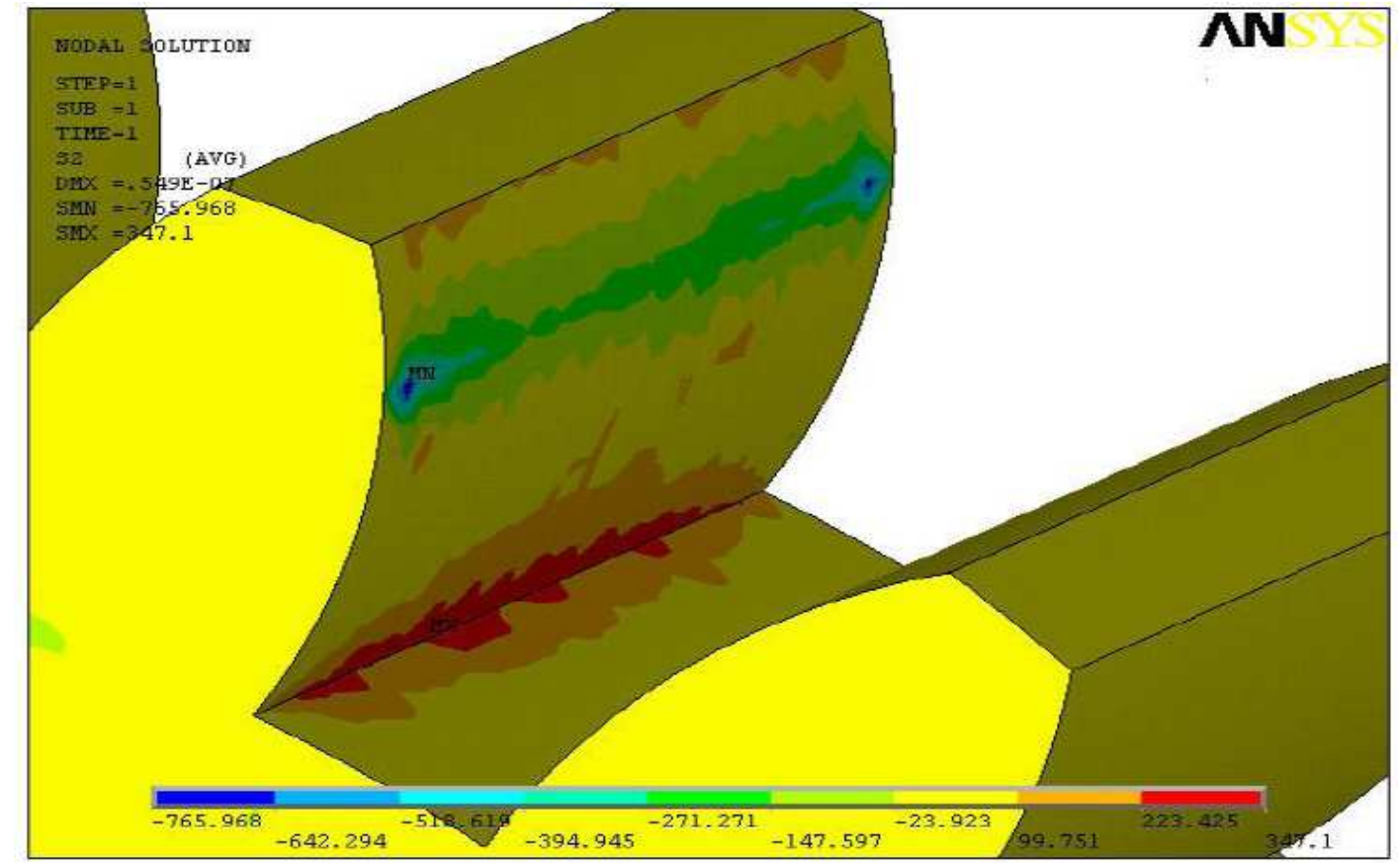

Fig. 12. Gear material: $35 \mathrm{CrMo} 4, \mathrm{~m}=4 \mathrm{~mm}, \mathrm{~b}_{1}=40 \mathrm{~mm}, \mathrm{z}_{2}=80$ and $\mathrm{P}_{\mathrm{wmax}}=116.789 \mathrm{~kW}$

Table 5. Deviation between Niemann's method results and FEM (ANSYS) results assuming GS-52 gear material and maximum rated power

\begin{tabular}{llrlllllr}
\hline $\begin{array}{l}\text { Gear } \\
\text { material }\end{array}$ & $\begin{array}{l}\text { Module } \\
(\mathrm{mm})\end{array}$ & $\mathrm{Z}_{2}$ & $\begin{array}{l}\mathrm{P}_{\mathrm{w} \max } \\
(\mathrm{kW})\end{array}$ & $\begin{array}{l}\mathrm{P}_{\mathrm{U}} \\
(\mathrm{N})\end{array}$ & $\begin{array}{l}\sigma_{\varepsilon \pi} \\
\left(\mathrm{N} / \mathrm{mm}^{2}\right)\end{array}$ & $\begin{array}{l}\sigma_{\max } \\
\left(\mathrm{N} / \mathrm{mm}^{2}\right)\end{array}$ & $\begin{array}{l}\text { ANSYS } \\
\left(\mathrm{N} / \mathrm{mm}^{2}\right)\end{array}$ & \multicolumn{1}{c}{$\%$} \\
\hline GS 52 & 1 & 30 & 0,983 & $1.043,28$ & 200 & 199,92 & 196,549 & 1.72 \\
& 2 & 50 & 8,118 & $4.307,05$ & 200 & 199,98 & 196,592 & 1.73 \\
& 2 & 80 & 12,442 & $6.601,17$ & 200 & 200,00 & 197,840 & 1.09 \\
& 3 & 100 & 37,621 & $13.306,69$ & 200 & 200,00 & 202,817 & -1.39 \\
& 3 & 100 & 47,027 & $16.633,62$ & 200 & 200,00 & 202,600 & -1.28 \\
& 4 & 80 & 66,357 & $17.603,04$ & 200 & 200,00 & 197,212 & 1.41 \\
& 5 & 30 & 49,178 & $10.436,66$ & 200 & 200,00 & 197,775 & 1.12 \\
& 5 & 50 & 25,370 & $5.384,08$ & 200 & 199,99 & 197,054 & 1.49 \\
& 6 & 80 & 64,697 & $11.441,78$ & 173,33 & 173,33 & 176,083 & -1.56 \\
& 6 & 100 & 130,420 & $23.065,02$ & 173,33 & 173,33 & 170,891 & 1.43 \\
\hline
\end{tabular}


Konstandinos G. Raptis et al. / American Journal of Engineering and Applied Sciences 5 (2) (2012) 205-216

Table 6. Deviation between Niemann's method results and FEM (ASNYS) results assuming Ck-60 gear material and maximum rated power

\begin{tabular}{|c|c|c|c|c|c|c|c|c|}
\hline $\begin{array}{l}\text { Gear } \\
\text { material }\end{array}$ & $\begin{array}{l}\text { Module } \\
(\mathrm{mm})\end{array}$ & $Z_{2}$ & $\begin{array}{l}P_{\mathrm{W} \max } \\
(\mathrm{kW})\end{array}$ & $\begin{array}{l}\mathrm{P}_{\mathrm{U}} \\
(\mathrm{N})\end{array}$ & $\begin{array}{l}\sigma_{\varepsilon \pi} \\
\left(\mathrm{N} / \mathrm{mm}^{2}\right)\end{array}$ & $\begin{array}{l}\sigma_{\max } \\
\left(\mathrm{N} / \mathrm{mm}^{2}\right)\end{array}$ & $\begin{array}{l}\text { ANSYS } \\
\left(\mathrm{N} / \mathrm{mm}^{2}\right)\end{array}$ & $\%$ \\
\hline \multirow[t]{10}{*}{ Ck 60} & 1 & 30 & 1.455 & 1.543 .92 & 296,00 & 295.86 & 290.860 & 1.72 \\
\hline & 2 & 50 & 12,015 & $6.374,63$ & 296,00 & 295,98 & 290,951 & 1.73 \\
\hline & 2 & 80 & 18,414 & $9.769,65$ & 296,00 & 296,00 & 292,796 & 1.09 \\
\hline & 3 & 100 & 55,681 & $19.694,58$ & 296,00 & 296,00 & 300,175 & -1.39 \\
\hline & 3 & 100 & 69.600 & $24.617,78$ & 296,00 & 296,00 & 299,835 & -1.28 \\
\hline & 4 & 80 & 98,209 & $26.052,67$ & 296,00 & 296,00 & 291,885 & 1.41 \\
\hline & 5 & 30 & 72.784 & $15.446,38$ & 296,00 & 296,00 & 292,722 & 1.12 \\
\hline & 5 & 50 & 37,549 & $7.968,73$ & 296,00 & 296,00 & 291,655 & 1.49 \\
\hline & 6 & 80 & 109,489 & $19.363,33$ & 293,33 & 293,33 & 297,980 & -1.56 \\
\hline & 6 & 100 & 220,713 & $39.033,50$ & 293,33 & 293,33 & 289,195 & 1.43 \\
\hline
\end{tabular}

Table 7. Deviation between Niemann's method results and FEM (ASNYS) results assuming 35CrMo4 gear material and maximum rated power

\begin{tabular}{llrlllllr}
\hline $\begin{array}{l}\text { Gear } \\
\text { material }\end{array}$ & $\begin{array}{l}\text { Module } \\
(\mathrm{mm})\end{array}$ & $\mathrm{Z}_{2}$ & $\begin{array}{c}\mathrm{P}_{\mathrm{wmax}} \\
(\mathrm{kW})\end{array}$ & $\begin{array}{l}\mathrm{P}_{\mathrm{U}} \\
(\mathrm{N})\end{array}$ & $\begin{array}{l}\sigma_{\varepsilon \pi} \\
\left(\mathrm{N} / \mathrm{mm}^{2}\right)\end{array}$ & $\begin{array}{l}\sigma_{\max } \\
\left(\mathrm{N} / \mathrm{mm}^{2}\right)\end{array}$ & $\begin{array}{l}\text { ANSYS } \\
\left(\mathrm{N} / \mathrm{mm}^{2}\right)\end{array}$ & \multicolumn{1}{c}{$\%$} \\
\hline 35 CrMo4 & 1 & 30 & 1,731 & $1.836,78$ & 352,00 & 351,98 & 346,032 \\
& 2 & 50 & 14,289 & $7.581,11$ & 352,00 & 352,00 & 346,017 & 1.72 \\
& 2 & 80 & 21,898 & $11.618,11$ & 352,00 & 352,00 & 348,206 & 1.09 \\
& 3 & 100 & 66,215 & $23.420,49$ & 352,00 & 352,00 & 356,964 & -1.39 \\
& 3 & 100 & 82,769 & $29.275,70$ & 352,00 & 352,00 & 356,567 & -1.28 \\
& 4 & 80 & 116,789 & $30.981,53$ & 352,00 & 352,00 & 347,100 & 1.41 \\
& 5 & 30 & 86,554 & $18.368,68$ & 352,00 & 352,00 & 348,102 & 1.12 \\
& 5 & 50 & 44,653 & $9.476,36$ & 352,00 & 352,00 & 346,834 & 1.49 \\
& 6 & 80 & 170,454 & $30.145,11$ & 456,66 & 456,66 & 4633,899 & -1.56 \\
& 6 & 100 & 343,609 & $60.767,89$ & 456,66 & 456,66 & 450,222 & 1.43 \\
\hline
\end{tabular}

Table 8. Review of deviations between Niemann's and FEM results for ten different gear materials and maximum rated power

\begin{tabular}{|c|c|c|c|c|c|c|c|c|}
\hline $\begin{array}{l}\text { Gear } \\
\text { material }\end{array}$ & $\begin{array}{l}\text { Module } \\
(\mathrm{mm})\end{array}$ & $Z_{2}$ & $\begin{array}{l}P_{\mathrm{w} \max } \\
(\mathrm{kW})\end{array}$ & $\begin{array}{l}\mathrm{P}_{\mathrm{U}} \\
(\mathrm{N})\end{array}$ & $\begin{array}{l}\sigma_{\varepsilon \pi} \\
\left(\mathrm{N} / \mathrm{mm}^{2}\right)\end{array}$ & $\begin{array}{l}\sigma_{\max } \\
\left(\mathrm{N} / \mathrm{mm}^{2}\right)\end{array}$ & $\begin{array}{l}\text { ANSYS } \\
\left(\mathrm{N} / \mathrm{mm}^{2}\right)\end{array}$ & $\%$ \\
\hline GS 52 & 1 & 30 & 0,983 & $1.043,28$ & 200 & 199,92 & 196,549 & 1.72 \\
\hline St 70 & 2 & 50 & 11,138 & $5.909,33$ & 274.4 & 274,38 & 269,700 & 1.73 \\
\hline $36 \mathrm{Mn} 5$ & 2 & 80 & 17,419 & $9.241,75$ & 280,00 & 280,00 & 276,984 & 1.09 \\
\hline Ck 60 & 3 & 100 & 55,681 & $19.694,58$ & 296,00 & 296,00 & 300,175 & -1.39 \\
\hline $37 \mathrm{Cr} 4$ & 3 & 100 & 73,833 & $26.115,01$ & 314,00 & 314,00 & 318,071 & -1.28 \\
\hline 42 Mnv7 & 4 & 80 & 106,172 & $28.165,07$ & 320,00 & 320,00 & 315,551 & 1.41 \\
\hline $35 \mathrm{CrMo} 4$ & 5 & 30 & 86,554 & $18.368,68$ & 352,00 & 352,00 & 348,102 & 1.12 \\
\hline $31 \mathrm{NiCr} 14$ & 5 & 50 & 47,190 & $10.014,77$ & 372,00 & 372,00 & 366,540 & 1.49 \\
\hline 34CrNiMo6 & 6 & 80 & 186,630 & $33.005,86$ & 500,00 & 500,00 & 507,923 & -1.56 \\
\hline $42 \mathrm{CrV} 6$ & 6 & 100 & 426,377 & $75.405,56$ & 566,66 & 566,66 & 558,671 & 1.43 \\
\hline
\end{tabular}

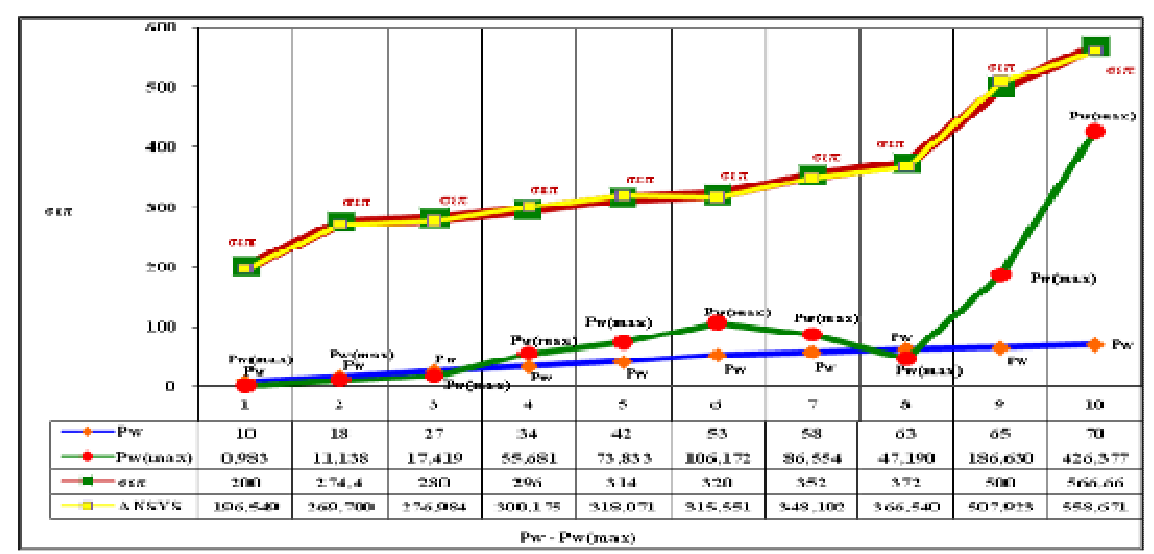

Fig. 13. Diagram of maximum allowable stress $\left(\sigma_{\varepsilon \pi}\right)$ versus power $\left(\mathrm{P}_{\mathrm{w}}\right)$ and maximum rated power $\left(\mathrm{P}_{\mathrm{wmax}}\right)$ 


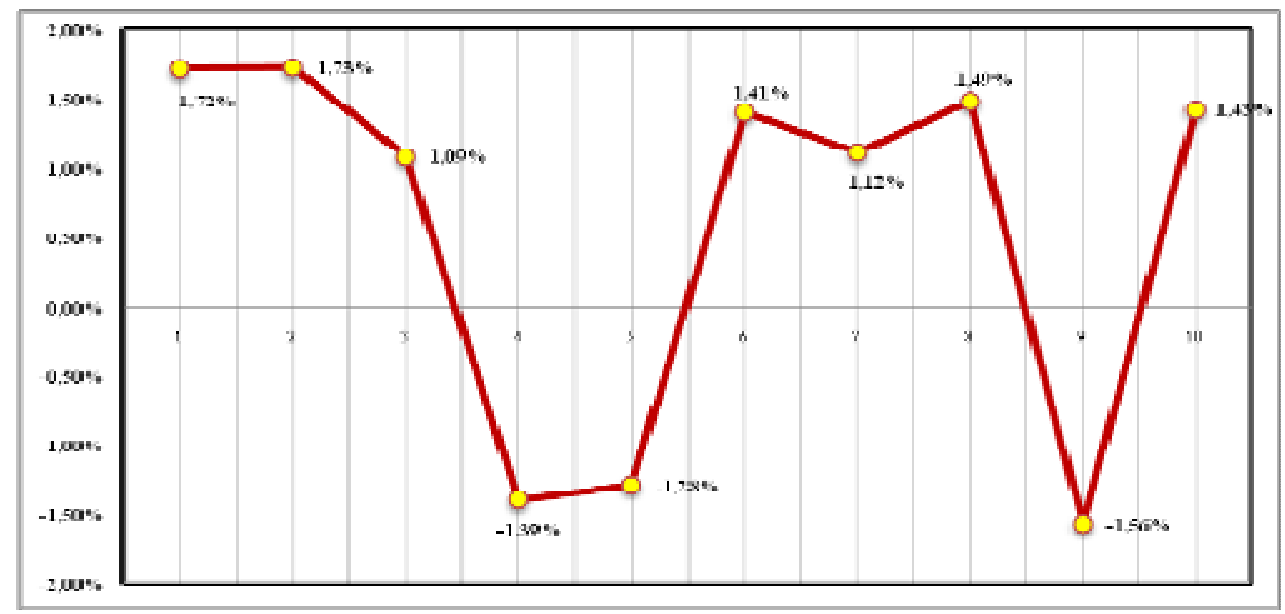

Fig. 14. Concentrating diagram of maximum stress $\left(\sigma_{\max }\right)$ deviation between Niemann's estimations and finite element results

From the previous considerations it was derived that deviations between the results of maximum allowable stresses $\left(\sigma_{\max }\right)$ calculated using theoretical methods and the Finite Element Method (FEM) with application of ANSYS software are commonly ranged between- $1.56 \%$ and $+.73 \%$, regardless of the transmitted power (random or maximum) and the respective tangential load, as shown in Table 1-6 as well as in concentrating Table 48 and Fig. 14.

\section{DISCUSSION}

Apart from the fatigue failure at the critically stressed point, small cracks at tooth surface have been observed at gear pitch circle (where the gear tooth is subjected to the total load), due to high pressure surface fatigue. Low viscosity lubricants can enter the cracks at high pressures. These initially small cracks can easily grow under the effect of high pressures of penetrating fluids, causing surface fatigue cracks or pitting. Therefore, it is critical to take into account the surface fatigue strength of gear during the design procedure.

\section{CONCLUSION}

This study investigated the minimum deviation of maximum allowable stress estimations at highest point of single tooth contact of meshing spur gear teeth using Niemann's formulas and finite element method with application of ANSYS software. Number of gear teeth, module and transmitted power were considered as variable parameters. For both loading cases (random and maximum transmitted power), common sets of other parameters $(\mathrm{m}$, $\mathrm{z}_{1}, \mathrm{z}_{2}$, material) derived identical deviations.
After comparison of the derived results using the discussed methods for both cases, it was concluded that deviations are acceptable, which is reasonable considering the potential errors that can be involved during the procedure.

\section{REFERENCES}

Dolan, T.J. and E.L. Broghamer, 1942. A photo-elastic study of stress in gear tooth fillets. Univ. Ill. Bull.

Heywood, R.B., 1962. Designing Against Fatigue of Metals. 1st Edn., Reinhold, New York, pp: 436.

Kawalec, A., J. Wiktor and D. Ceglarek, 2006. Comparative analysis of tooth-root strength using ISO and AGMA standards in spur and helical gears with FEM-based verification. J. Mech. Des., 128: 1141-1158. DOI: $10.1115 / 1.2214735$

Lewis, W., 1882. Investigation of the strength of gear teeth. Proceedings of the Engineering Club No. 1, (FC' 82), Philadelphia, pp: 16-23.

Niemann, G., 1982. Machine Elements: Gears. 1st Edn., Springer-Varlag, Berlin, ISBN: 3540033785.

Spitas, V., T.H. Costopoulos and C. Spitas, 2005. Increasing the strength of standard involute gear teeth with novel circular root fillet design. Am. J. Applied Sci., 2: 1058-1064. DOI: 10.3844/ajassp.2005.1058.1064 